\title{
INJECTED HISTONE ANTIBODIES INTERFERE WITH TRANSCRIPTION OF LAMPBRUSH CHROMOSOME LOOPS IN OOCYTES OF
}

\author{
PLEURODELES
}

\author{
U. SCHEER*, J. SOMMERVILLE AND M. BUSTIN** \\ Department of Zoology, University of St Andrews, St Andrezws, KYI6 9TS Scotland \\ and ${ }^{*} *$ Laboratory of Molecular Carcinogenesis, National Cancer Institute, National \\ Institutes of Health, Bethesda, Maryland 20205, U.S.A.
}

\section{SUMMARY}

Antibodies to calf thymus histone $\mathrm{H}_{2} \mathrm{~B}$ were purified by chromatography on DEAE-cellulose and injected into oocyte nuclei of Pleurodeles waltiii. As shown by indirect immunofluorescence these antibodies cross-reacted strongly with corresponding histones associated with lampbrush chromosomes. Shortly after injection the lateral loops of the chromosomes retracted into the chromomeres and by $3 \mathrm{~h}$ postinjection the 'lampbrush' appearance was completely lost and the chromosomes appeared in light-microscopic preparations as rod-like structures consisting of longitudinally coalesced chromomeres. In control oocytes injected with non-immune immunoglobulins or antibodies against a ubiquitous transcript-associated protein no morphological alterations of the lampbrush chromosomes could be observed. Electron microscopic spreads of chromosomes prepared at various times after injection of anti- $\mathrm{H}_{2} \mathrm{~B}$ revealed a progressive loss of transcriptional complexes from the loop axes. Finally, higher-order chromatin configurations, like supranucleosomal globules ('superbeads') or cable-like chromatin strands 50-60 $\mathrm{nm}$ thick predominated, indicating complete transcriptional inactivation of all chromosomal regions. The results indicate that $\mathrm{H}_{2} \mathrm{~B}$ antibodies react specifically with histones associated with the transcribed DNA of lateral loops in their native state. The resulting antigenantibody complexes seem to inhibit progression of the RNA polymerases along the template, thus causing the premature release of transcripts, a process analogous to the stripping effect of actinomycin D. The demonstration of histones associated with heavily transcribed regions, which are not compacted into nucleosomes but largely extended, supports the current concept that unfolding of nucleosomes to allow transcription of the DNA does not involve dissociation of histones. In contrast, amplified ribosomal RNA genes are unaffected by injected $\mathrm{H}_{2} \mathrm{~B}$ antibodies. This does not necessarily indicate absence of histones from nucleolar chromatin, since we do not know whether it is accessible in vivo to antibodies or whether the histone antigenic determinants are masked by the presence of other proteins. The technique of injecting specific antibodies should be widely applicable when analysing the in vivo distribution of chromosomal components at the electron-microscopic level and when studying complex metabolic processes, like the cleavage and modification of RNA, by selective inhibition of defined enzymic steps.

* Permanent address: Division of Membrane Biology and Biochemistry, Institute of Experimental Pathology, German Cancer Research Center, D-69 Heidelberg, Federal Republic of Germany. 


\section{INTRODUCTION}

Lampbrush chromosomes of amphibian oocytes contain several thousands of highly active genes which, in electron-microscopic sptead preparations, appear as transcriptional units densely covered by numerous transcriptional complexes (Miller \& Bakken, 1972; Miller, Beatty \& Hamkalo, 1972; Angelier \& Lacroix, 1975; Sommerville \& Malcolm, I976; Scheer, Franke, Trendelenburg \& Spring, 1976; Scheer, Spring \& Trendelenburg, I979; Franke et al. 1976; Malcolm \& Sommerville, 1977). The close to maximum packing density of the transcribing RNA polymerases would leave little, if any, space for interspersed nucleosomes and in fact particles of nucleosomal size are not detectable between adjacent RNA polymerases (Franke et al. 1976). This observation and several other lines of evidence strongly suggest that the DNA of the heavily transcribed lateral loop axes is largely extended to the length equivalent to its B-conformation and not compacted into nucleosomes (summarized in Franke et al. 1976, 1978; Scheer et al. 1979). In somatic cells a similar extension of the chromatin sections engaged in transcription seems to occur when they are saturated with RNA polymerases, i.e. in states of full transcriptional activity (McKnight, Sullivan \& Miller, I976; see also McKnight, Bustin \& Miller, I978). On the other hand, towards the end of oocyte growth, when the frequency of transcriptional complexes is drastically reduced as a consequence of a progressive transcriptional inactivation, the chiomatin intercepts between 2 now distantly spaced transcripts usually reveal a beaded appearance. These 'beads' in the direct neighbourhood of RNA polymerases have been identified as nucleosomes by their lability towards de-histonization using the anionic detergent Sarkosyl (Scheer, 1978).

Transcribed nonribosomal chromatin from a variety of somatic cells generally bears a relatively low number of transcriptional complexes (e.g. Miller \& Bakken, I972; Kierszenbaum \& Tres, 1975; Foe, Wilkinson \& Laird, 1976; Laird, Wilkinson, Foe \& Chooi, 1976; McKnight \& Miller, 1976; McKnight et al. 1978; Puvion-Dutilleul, Bernadac, Puvion \& Bernhard, I977; Busby \& Bakken, I979). Similar to the situation found in maturing oocytes, the chromatin sections of such sparsely transcribed regions, which at the very moment of preparation are not being transcribed, have a beadlike appearance, provided that chromatin dispersal and spreading are carried out under conditions that preserve nucleosomal integrity (Foe et al. 1976; Laird et al. I976; McKnight \& Miller, I976; McKnight et al. 1978; Busby \& Bakken, 1979). The nucleosomal nature of these particles has been established by electron-microscopic immunolocalization procedures using specific histone antibodies (McKnight et al. 1978). The conclusion that the chromatin of such nonribosomal transcriptional units is arranged in nucleosomes is in accordance with nuclease digestion experiments showing that the DNA of several active genes is not randomly digested by micrococcal nuclease but cleaved into discrete (about 200 base pairs) fragments, analogous to the digestion pattern generated by the association with histones (e.g. Garel \& Axel, 1978; Bellard, Gannon \& Chambon, 1978).

Assuming that a nucleosome has to unfold in order to allow transcription of the DNA by an RNA polymerase molecule, it follows that its reformation must be a 
relatively fast process after the passage of the polymerase. It should be emphasized that this immediate nucleosome reformation is observed only in nonribosomal transcriptional units and is contrary to the situation found in ribosomal RNA genes (Foe, I978; Scheer, I978). However, it is not known whether unfolding and reformation of nucleosomes represent merely structural transitions of the nucleoprotein complex or whether an actual physical displacement of histones from the DNA is involved (for detailed discussion see Weintıaub, Worcel \& Alberts, I976; Wasylyk, Thevenin, Oudet \& Chambon, I979). Heavily transcribed genes like those present in growing amphibian oocytes should provide a means for discriminating between these 2 possible mechanisms because, due to the rapid succession of transcriptional events, their chromatin appears to be in a long-sustained 'unfolded' state. If the mechanism of transcription involves transient dissociation of histones from the DNA, then a sequence of transcriptional processes fast enough to prevent the reformation of nucleosomes should manifest itself in an apparent absence of histones from such regions.

Although immunofluorescence techniques have been applied successfully for the localization of certain transcript-associated proteins, as well as for histones in the non-transcribed chromomeric regions of amphibian lampbrush chromosomes, the special cytological situation of highly extended lateral loops surrounded by a comparatively huge mass of ribonucleoprotein (RNP) matrix material does not allow us to resolve, using such a technique, the question as to whether histones are associated with the loop DNA (Sommerville, Crichton \& Malcolm, 1978). We have developed therefore a different approach which is nevertheless based on the availability of highly reactive antibodies to purified histones (Goldblatt \& Bustin, I975; Simpson \& Bustin, I976). We have injected antibodies directly into oocyte nuclei and have studied the biological effect of their interaction with histones in vivo, at both the light- and electron-microscopic levels.

\section{MATERIALS AND METHODS}

\section{Animals}

Females of Pleurodeles waltiii were purchased from Station d'acclimation et d'élevage, Bouillé-St Paul, France, and kept in water tanks at $20^{\circ} \mathrm{C}$.

\section{Antibodies}

Antibodies against purified calf thymus histone $\mathrm{H}_{2} \mathrm{~B}$ were elicited in rabbits and characterized as described (Goldblatt \& Bustin, 1975; Simpson \& Bustin, 1976). The antiserum was shipped in a lyophilized state and reconstituted with double-distilled water before being used.

Antibodies were prepared against nuclear ribonucleoprotein (RNP) extracted from oocytes of Triturus cristatus carnifex as described previously (Sommerville et al. 1978). The antiserum used in the experiments described here was against a major acidic protein fraction recovered after column chromatography of solubilized nuclear RNP on DEAE-cellulose (DEAE-A25, Sephadex) according to the method of Karn, Vidali, Baffa \& Allfrey (r977). The oocyte nuclear $\mathrm{RNP}$ was first treated with $\mathrm{I} \mu \mathrm{g} / \mathrm{ml}$ ribonuclease $\mathrm{A}$ at $0^{\circ} \mathrm{C}$ for $30 \mathrm{~min}$, then solubilized in a solution containing $6 \mathrm{M}$ urea, ro $\mathrm{mm}$ Tris- $\mathrm{HCl} \mathrm{pH} \mathrm{8,} \mathrm{го} \mathrm{mM} \mathrm{KCl,} \mathrm{дmм} \mathrm{2-mercaptoethanol.}$ After elution of the basic proteins from the column with this solution, the acidic proteins were eluted with the same solution containing I M KCl. The first peak absorbing at $280 \mathrm{~nm}$ was collected, dialysed against ro $\mathrm{mM} \mathrm{KCl}$, Iо $\mathrm{mm}$ Tris- $\mathrm{HCl} \mathrm{pH} \mathrm{7.5,} \mathrm{I} \mathrm{mM} \mathrm{2-mercaptoethanol} \mathrm{and}$ 
injected into rabbits in the form of multiple emulsions (Sommerville et al. 1978). The antiserum to this component of Triturus oocyte nuclear RNP cross-reacted with the chromatin of various other amphibian species as well as with the chromatin of mammalian cells (Whitfield \& Sommerville, unpublished).

The immunoglobulin (Ig) fractions from immune and control sera were obtained by column chromatography on DEAE-cellulose (DE 52, Whatman) as outlined by Bustin, Simpson, Sperling \& Goldblatt (I977), except that elution was performed with 0.015 M sodium phosphate buffer $(\mathrm{pH} 8 \cdot 0)$. The Ig fraction in the early eluting peak was concentrated by dialysis against $25 \%$ polyethyleneglycol and finally dialysed against $0.1 \mathrm{M} \mathrm{NaCl}$, IO $\mathrm{mm}$ Tris- $\mathrm{HCl} \mathrm{pH} 7 \cdot 4$ (TBS). Antibody concentrations were determined photometrically based on a $\mathrm{I} \mathrm{mg} / \mathrm{ml}$ solution of Ig having an optical density of $\mathrm{I} \cdot 4$ at $280 \mathrm{~nm}$. Aliquots were stored at $-70^{\circ} \mathrm{C}$ and thawed immediately prior to use.

\section{Oocyte injection}

A piece of ovary was removed from an anaesthetized Pleurodeles and placed in modified. Barth medium (Gurdon, I976) containing 50 units $/ \mathrm{ml}$ each of penicillin, streptomycin and kanamycin. Oocytes with diameters from $\mathrm{I} \cdot 0$ to $\mathrm{I} \cdot 2 \mathrm{~mm}$ were mechanically freed from their follicle epithelium and centrifuged at $150 \mathrm{~g}$ for $20 \mathrm{~min}$ to translocate the nucleus to the animal pole, thereby facilitating the nuclear injection (Kressmann, Clarkson, Telford \& Birnstiel, I978). Into each oocyte nucleus Io $\mathrm{nl}$ of serum or Ig solution were injected using the procedure described by Gurdon (1974).

\section{Light microscopy of lampbrush chromosomes}

At $\mathrm{I}-24 \mathrm{~h}$ after injection, individual oocytes were transferred into Tris-buffered ' 3 : $\mathrm{I}$ medium' ( $75 \mathrm{~mm} \mathrm{KCl}, 25 \mathrm{mM} \mathrm{NaCl}$, $10 \mathrm{~mm}$ Tris- $\mathrm{HCl} \mathrm{pH} \mathrm{7.2)} \mathrm{and} \mathrm{the} \mathrm{nuclei} \mathrm{were} \mathrm{isolated}$ manually under a dissecting microscope. Lampbrush chromosomes were prepared in the same medium adjusted to o. I $\mathrm{mM} \mathrm{CaCl}_{2}$ as described by Callan \& Lloyd (I960). Photographs were taken under phase-contrast using an inverted Zeiss-microscope equipped with a flash.

\section{Electron microscopy of lampbrush chromosomes and amplified nucleoli}

Spread preparations were made essentially according to the procedure described by Miller \& Bakken (1972). Briefly, nuclear contents were dispersed for various times (2-I0 $\mathrm{min}$ ) in $0.1 \mathrm{mM}$ borate buffer, $\mathrm{pH} 9$, and centrifuged through $\mathrm{I} \%$ paraformaldehyde, $\mathrm{O} . \mathrm{I} \mathrm{M}$ sucrose on to freshly glow-discharged, carbon-coated grids. After staining in ethanolic $\mathrm{r} \%$ phosphotungstic acid, dehydrating in 96 and $100 \%$ ethanol and air drying, the grids were rotary shadowed with $\mathrm{Pt} / \mathrm{Pd}(80: 20)$ at an angle of ca. $8^{\circ}$ and examined in a Philips $30 \mathrm{r}$ electron microscope.

\section{Immunofluorescence}

Lampbrush chromosomes were prepared as described above and centrifuged at $2000 \mathrm{~g}$ for ro min in order to attach them firmly to the glass coverslip (Sommerville et al. 1978). The centrifugation chamber was then transferred into $70 \%$ ethanol for $5 \mathrm{~min}$ followed by several rinses in TBS. Immunoglobulins were then added at a concentration of $20 \mu \mathrm{g} / \mathrm{ml}$. After $30 \mathrm{~min}$ at room temperature the preparations were thoroughly washed with several changes of TBS over a total period of $30 \mathrm{~min}$, and were then further incubated with FITC-conjugated antirabbit IgG (Miles-Yeda) at a dilution of $\mathrm{I}: \mathrm{r} 00$ for $30 \mathrm{~min}$. After washing in several changes of TBS $(\mathrm{pH} \mathrm{8.0)} \mathrm{the} \mathrm{glass} \mathrm{coverslip} \mathrm{was} \mathrm{removed} \mathrm{from} \mathrm{the} \mathrm{centrifugation} \mathrm{chamber} \mathrm{and} \mathrm{mounted}$ with glycerol/TBS in a ratio of 9: $\mathrm{I}$. Photographs were taken with a Zeiss-fluorescence microscope on Kodak Tri-X Pan films. 
RESULTS

\section{Purification of the antisera}

After injection of $\mathrm{I} 0 \mathrm{nl}$ of complete rabbit serum at dilutions ranging from $\mathrm{I}$ : $\mathrm{s}$ o to I : Ioo into nuclei of Pleurodeles oocytes we consistently observed drastic morphological alterations to the lampbrush chromosomes. One hour after injection the 'lampbrush' appearance was completely lost due to the absence of any visible lateral loops and the chromomeres were condensed into relatively short, rod-like structures. Since this effect was independent of the specific serum used, nucleases and/or proteases present in the sera (c.f. Simpson \& Bustin, 1976) evidently caused the disappearance of the lateral loops, similar to the stripping effect observed after treatment of lampbrush chromosome preparations with such enzymes (Macgregor \& Callan, ig62).

After separation of the Ig fraction from nonimmune rabbit serum by chromatography on DEAE-cellulose and injection of IO-nl aliquots of Ig adjusted to a protein concentration similar to that of the injected serum, this stripping of lateral loop matrix was no longer observed. Chromosomes prepared I to $24 \mathrm{~h}$ after injection of nonimmune rabbit $\mathrm{Ig}$ at a concentration of $2.2 \mathrm{mg} / \mathrm{ml}$ were normal in all respects as compared to those from untreated oocytes. Therefore, to avoid enzymic disruption of chromosomal structures all sera were purified in this way prior to injection.

\section{Specificity of the antibodies}

Before the morphological changes to lampbrush chromosomes upon injection of antibodies can be discussed and interpreted it is important to demonstrate the specificity in the reaction of the antibodies used with chromosomal proteins. For this put pose we have chosen the immuno-fluorescent localization method which has been developed recently to study the distribution of transcript-associated proteins in lampbrush chromosomes (Scott \& Sommerville, I974; Sommerville et al. 1978). Preliminary experiments have shown that incubation of lampbrush chromosome preparations with non-immune Ig at concentrations above $20 \mu \mathrm{g} / \mathrm{ml}$ causes nonspecific staining of the chromomeres as well as of the lateral loops, similar to the nonspecific binding observed after treatment with complete rabbit serum above a I : 500 dilution (Sommerville et al. I978). Therefore, all chromosome preparations were treated with Ig concentrations of $20 \mu \mathrm{g} / \mathrm{m}$, which gave a negligible faint background fluorescence (Fig. IE).

Anti- $\mathrm{H}_{2} \mathrm{~B}$ reacted strongly with the chromomeres of the lampbrush chromosomes, a finding which is not unexpected considering the fact that the transcriptionally inactive chromatin of these regions is compacted into nucleosomes and higher order structures (see below and Scheer, r978; Scheer \& Sommerville, r979). The strong reaction confirms earlier findings of a high evolutionary stability of histone $\mathrm{H}_{2} \mathrm{~B}$ using a variety of other heterologous antigen-antibody combinations (e.g. Stollar \& Ward, I970; Bustin et al. I978.) The fluorescence along the lateral loops is more difficult to explain because it apparently follows the distribution of the RNP matrix material instead of being restricted to a delicate centrally located DNP axis (Fig. I A). In a more 

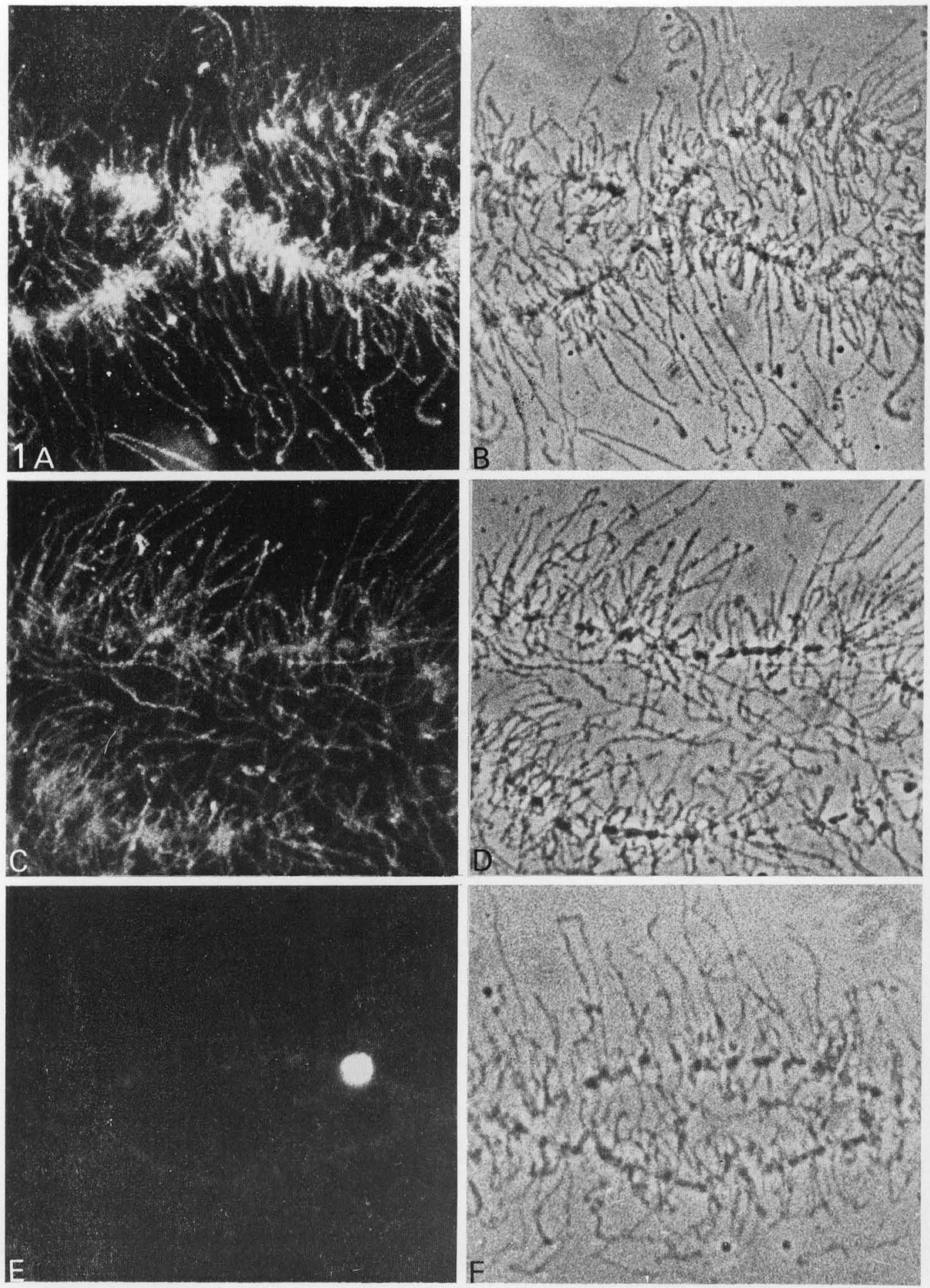
detailed analysis we will present evidence that the specific reaction of $\mathrm{H}_{2} \mathrm{~B}$ antibodies with the RNP matrix tends to obscure the binding to the loop axis proper (Sommerville and Scheer, unpublished).

Treatment of the chromosomes with antibodies against RNP-protein resulted in a completely different fluorescence pattern (Fig. I c). The chromomeres no longer stood out as intensely stained structures but instead a selective fluorescence over the lateral loops was noted (Fig. I C). The target proteins to this antiserum, therefore, seem to represent an ubiquitous component of the transcripts whose antigenic determinants were conserved at least between the urodelan species Triturus and Pleurodeles (for further discussion see Sommerville et al. I978).

\section{Morphology of lampbrush chromosomes after injection of antibodies}

Light-microscopic appearance. The concentrations of all Ig solutions used for injection were adjusted to $\mathrm{I} \cdot 6 \mathrm{mg} / \mathrm{ml}$ with TBS. Although aliquots of $\mathrm{I}$ o $\mathrm{nl}$ were injected into each oocyte nucleus, even doubling of this volume did not cause any visible morphological alterations to the chromosomes when nonimmune Ig was used. A typical aspect of a chromosome bivalent isolated $3 \mathrm{~h}$ after injection of nonimmune $\mathrm{Ig}$ is presented in Fig. $2 \mathrm{~A}$. The general appearance is indistinguishable from that of the corresponding bivalent isolated from an untreated oocyte of the same size class.

After injection of anti- $\mathrm{H}_{2} \mathrm{~B}$ immunoglobulins the morphology of the chromosomes changed drastically. As soon as $30 \mathrm{~min}$ after injection the first signs of loop retraction could be observed and this was usually complete by $3 \mathrm{~h}$ after injection (Fig. 2 B, C). Small groups of lateral loops, however, could occasionally still be observed at particular regions of the chromosomes, indicating a certain heterogeneity in their response after injection of anti- $\mathrm{H}_{2} \mathrm{~B}$. The gradual retraction of the loops was followed by a size increase of the chromomeres, which finally amalgamated longitudinally into compact rod-like structures (Fig. 2 B, C). In regions where loop retraction was completed both axes of each bivalent came close together, sometimes giving the impression that they were wound around each other (Fig. 2 B, C).

Injection of antibodies against transcript-associated proteins did not cause any visible morphological change of the lampbrush chromosomes (Fig. 2 D). Their appearance remained identical to that of the controls (Fig. $2 \mathrm{~A}$ ).

Taken together, these findings indicate that the loop retraction after injection of anti- $\mathrm{H}_{2} \mathrm{~B}$ is caused by the specific interaction of these antibodies with DNA-associated histones and is not a result of the binding to the RNP matrix.

Electron-microscopic appearance. Having established that injection of anti- $\mathrm{H}_{2} \mathrm{~B}$ leads to loop retraction, indicating inhibition of transcription, we wondered whether

Fig. r. Immunofluorescence of Pleurodeles lampbrush chromosomes treated with antibodies against calf thymus $\mathrm{H}_{2} \mathrm{~B}$ (A) and RNP protein (c). The histone antibodies bind preferentially to the dense chromomeric axes (A) whereas the antibodies against RNP protein stain selectively the lateral loops (c). In phase contrast the chromomeres appear as linear arrays of dark granules from which extend the lateral loops (B, D, F). All preparations were treated with Ig fractions at a concentration of $20 \mu \mathrm{g} / \mathrm{ml}$. Nonimmune Ig gave negligible background fluorescence $(\mathrm{E}) . \times$ I 300 . 

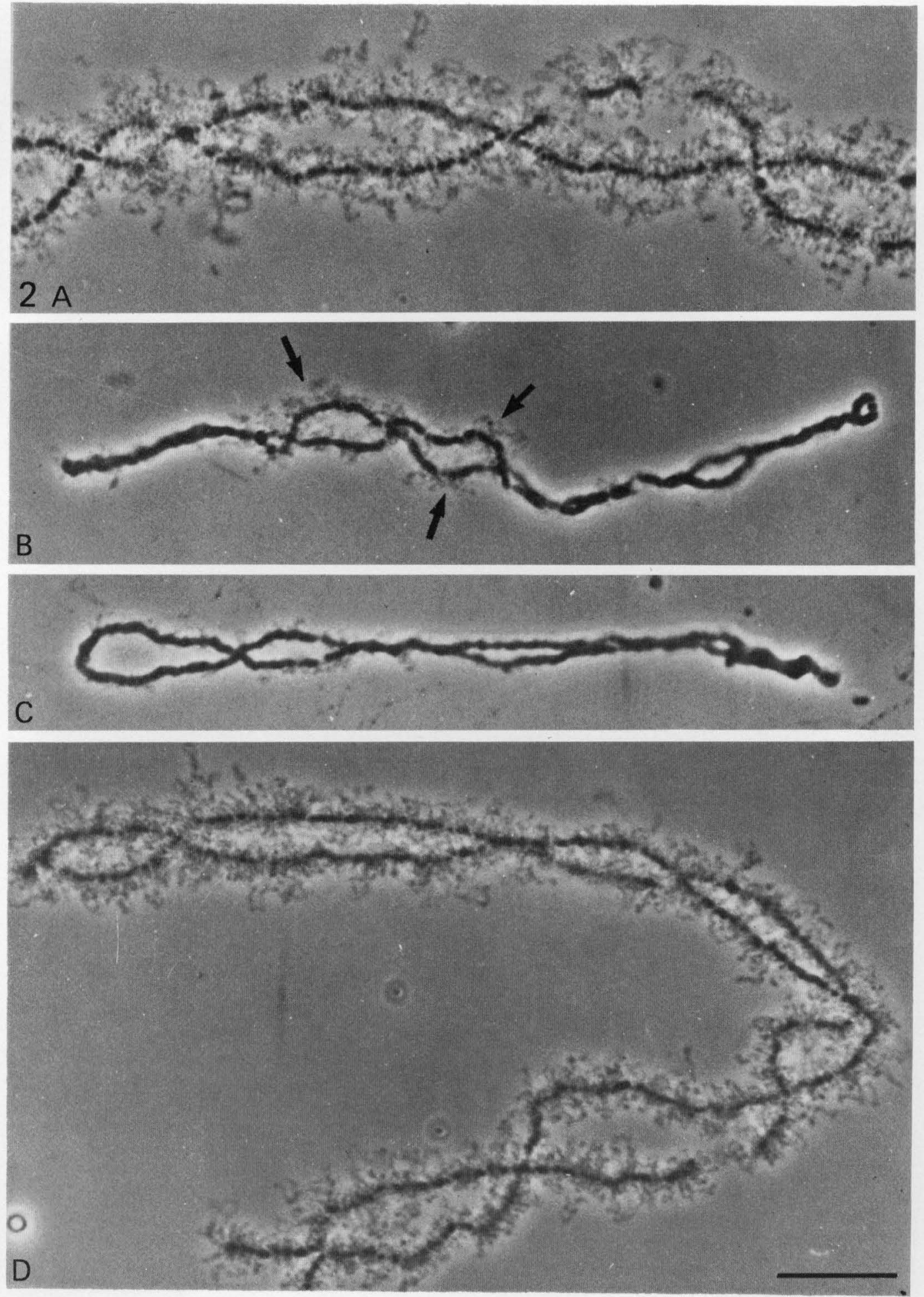
this was reflected by an altered arrangement of transcripts similar to the situation described in nearly mature oocytes where a natural loop retraction occurs in preparation for first metaphase of meiosis (Scheer, I978). Electron-microscopic spread preparations of control oocytes which were injected with non-immune $\mathrm{Ig}$, as well as of oocytes injected with anti-RNP, revealed the presence of the characteristic chromosomal transcriptional units of varying lengths (up to $40 \mu \mathrm{m}$ long) densely covered by lateral fibrils (Figs. 3, 4; for further details see Miller et al. 1972; Angelier \& Lacroix, I975; Scheer et al. 1976, I979). The centre-to-centre distance of the RNA polymerases in these regions was usually about $\mathrm{r}^{-20} \mathrm{~nm}$ (Fig. 4). A beaded organization of the chromatin axis was apparent only in regions preceding or following a transcriptional unit (Fig. 4).

In spreads prepared $60 \mathrm{~min}$ after anti-H2B injection, transcribed chromatin could still be recognized but with a much reduced frequency of attached lateral fibrils (Fig. 5). The distances between the transcripts varied greatly, i.e. long stretches of transcript-free intercepts alternated with regions where small groups of transcriptional complexes had retained their original close juxtaposition (Fig. 5). The transcript-free chromatin intercepts had a beaded contour indicative of their nucleosomal organization (Fig. 5). At $4 \mathrm{~h}$ after injection of anti- $\mathrm{H}_{2} \mathrm{~B}$ immunoglobulins transcript-associated chromatin like that shown in Fig. 6 was found only very rarely and instead inactive chromatin arranged in nucleosomes or higher-order structures predominated (Figs. 7-9). The situation seen in Fig. 6 presumably reflects some residual transcriptional activity along the chromatin strand extending from the periphery of a chromomere. Both the chromomeric and the transcribed chromatin had the same characteristic beaded appearance and, based on their identity in size and staining behaviour, it seems unlikely that the particles within a transcribed region represent RNA polymerases free of lateral RNP fibrils.

Besides being arranged in nucleosomes, inactive chromatin was frequently organized into higher-order packing structures like supranucleosomal globular units ('superbeads' according to Hozier, Renz \& Nehls, I977) or 50-60 nm thick cable-like strands (Figs. 7-9). All three different chromatin aspects were usually found closely intermingled and in structural continuities suggesting that they represent a series of hierarchical packing structures (Fig. 7). The 'superbeads' often occurred in well defined areas (Fig. 7) in very tight linear arrangements thus forming a network of

Fig. 2. Lampbrush chromosomes isolated from Pleurodeles oocytes which had been injected with non-immune $\operatorname{Ig}(\mathrm{A})$, anti- $\mathrm{H}_{2} \mathrm{~B}(\mathrm{~B}, \mathrm{C})$ and antibodies against RNP protein (D). Chromosomes were isolated $3 \mathrm{~h}$ after injection of the $\mathrm{Ig}$ fractions $(\mathrm{r} \cdot 6 \mathrm{mg} / \mathrm{ml}$, total volume $\mathrm{so} \mathrm{nl})$ into the nuclei and were photographed unfixed under phase contrast. Injection of anti- $\mathrm{H}_{2} \mathrm{~B}$ leads to retraction of the lateral loops and fusion of the chromomeres $(\mathrm{B}, \mathrm{C})$. The overall condensation brings about a shortening of the chromosomal length. Although the vast majority of lateral loops are completely retracted within $3 \mathrm{~h}$, a few are still extended at this time (arrows in B). Accompanied by the overall condensation of chromatin is a close lateral association of homologous chromosomes along substantial parts of their length. Around the condensed chromosomes occasional networks of fine fibrillar material are seen (c). $\times 900$; bar indicates $20 \mu \mathrm{m}$. 

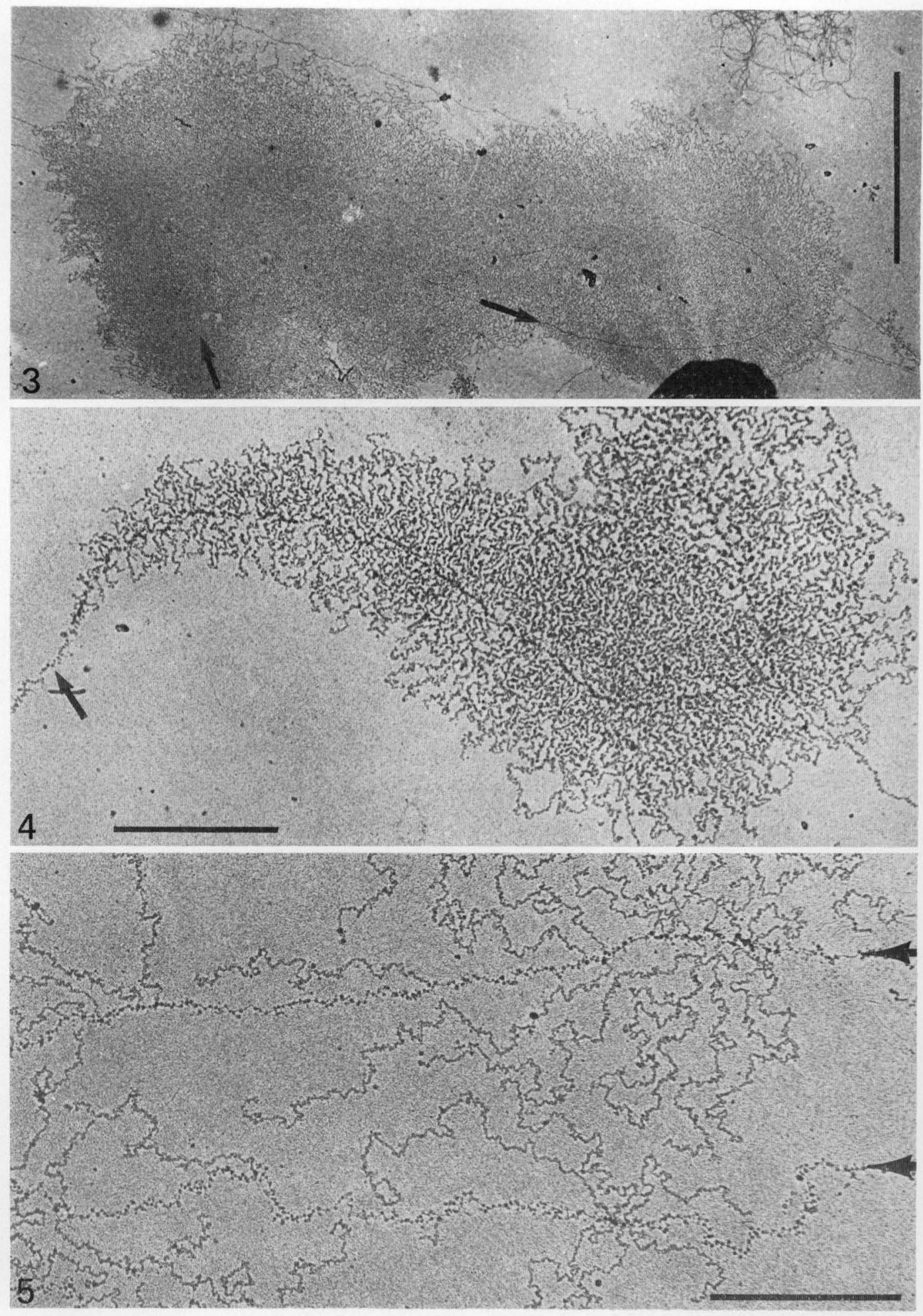
chromatin fibrils $c a .30 \mathrm{~nm}$ thick (Fig. 8; cf. also Scheer \& Sommerville, I979). The chromatin 'cables' had a conspicuous irregular contour and sometimes seemed to unfold into complex arrays of superbeads (Fig. 9). It should be noted that such higher order structures occurred also in control preparations but to a much lesser extent. (A more detailed description and account of their occurrence in amphibian oocytes, and of their relationship to higher-order chromatin structures in somatic cells of other species, will be presented in a forthcoming paper.)

\section{Morphology of amplified ribosomal RNA genes after injection of antibodies}

Quite unexpectedly, the appearance of transcribing ribosomal RNA genes was not changed by injection of antibodies against either RNP protein or $\mathrm{H}_{2} \mathrm{~B}$. Fig. Io presents a group of apparently fully active genes $4 \mathrm{~h}$ after injection of anti- $\mathrm{H}_{2} \mathrm{~B}$. Nearly all of them are densely covered by transcriptional complexes of increasing lengths resulting in the characteristic 'Christmas tree' appearance, and they cannot be distinguished from the corresponding genes of control oocytes (c.f. Angelier \& Lacroix, 1975; Franke et al. 1978).

\section{DISCUSSION}

The antibodies against calf thymus $\mathrm{H}_{2} \mathrm{~B}$ which were used for the injection experiments described in this study have been shown to interact specifically with the histone species $\mathrm{H}_{2} \mathrm{~B}$ (Goldblatt \& Bustin, 1975) and to bind in a highly specific manner to chromosomes, chromatin and nucleosomes (Bustin, 1973; Bustin, Goldblatt \& Sperling, 1976a; Bustin et al. 1976b; Simpson \& Bustin, 1976; Kurth, Moudrianakis \& Bustin, 1978; McKnight et al. 1978). Due to the conservative nature of histone $\mathrm{H}_{2} \mathrm{~B}$ (Elgin \& Weintraub, 1975) this antiserum has been applied successfully as a universal probe to study the organization of $\mathrm{H}_{2} \mathrm{~B}$ in chromatin from several widely distant species using immuno-cytochemical localization techniques (cf. Bustin et al. 1978). The use of such heterologous immunological reactions ensures that binding of the antiserum is due to cross-reacting histone determinants and does not include tissue- or species-specific nonhistone proteins.

Fig. 3. Electron micrograph showing at low magnification a chromosomal transcription unit with a total length of $35 \mu \mathrm{m}$ from a Pleurodeles oocyte injected with nonimmune Ig. Note the high packing density of the lateral RNP fibrils. In terminal regions of the transcription unit the DNP axis is hardly visible due to the large amount of RNP material (the arrows point to the DNP axis). $\times 5700$; bar indicates $5 \mu \mathrm{m}$.

Fig. 4. Same preparation as used for Fig. 3 showing the start region of another transcriptional unit. The basal particles of the lateral fibrils, containing the RNA polymerases, are so tightly packed that they often form a continuous thickening of the DNP axis. The nontranscribed chromatin stretch preceding the transcription unit has a beaded appearance (arrow). $\times 25000$; bar indicates $\mathrm{I} \mu \mathrm{m}$.

Fig. 5. Electron micrograph of a spread preparation $60 \mathrm{~min}$ after injection of anti$\mathrm{H}_{2} \mathrm{~B}$. The DNP axis of a chromosomal loop (denoted by the 2 arrows on the right) is sparsely covered with lateral fibrils. The transcript-free chromatin intercepts have a beaded appearance. $\times 28000$; bar indicates I $\mu \mathrm{m}$. 


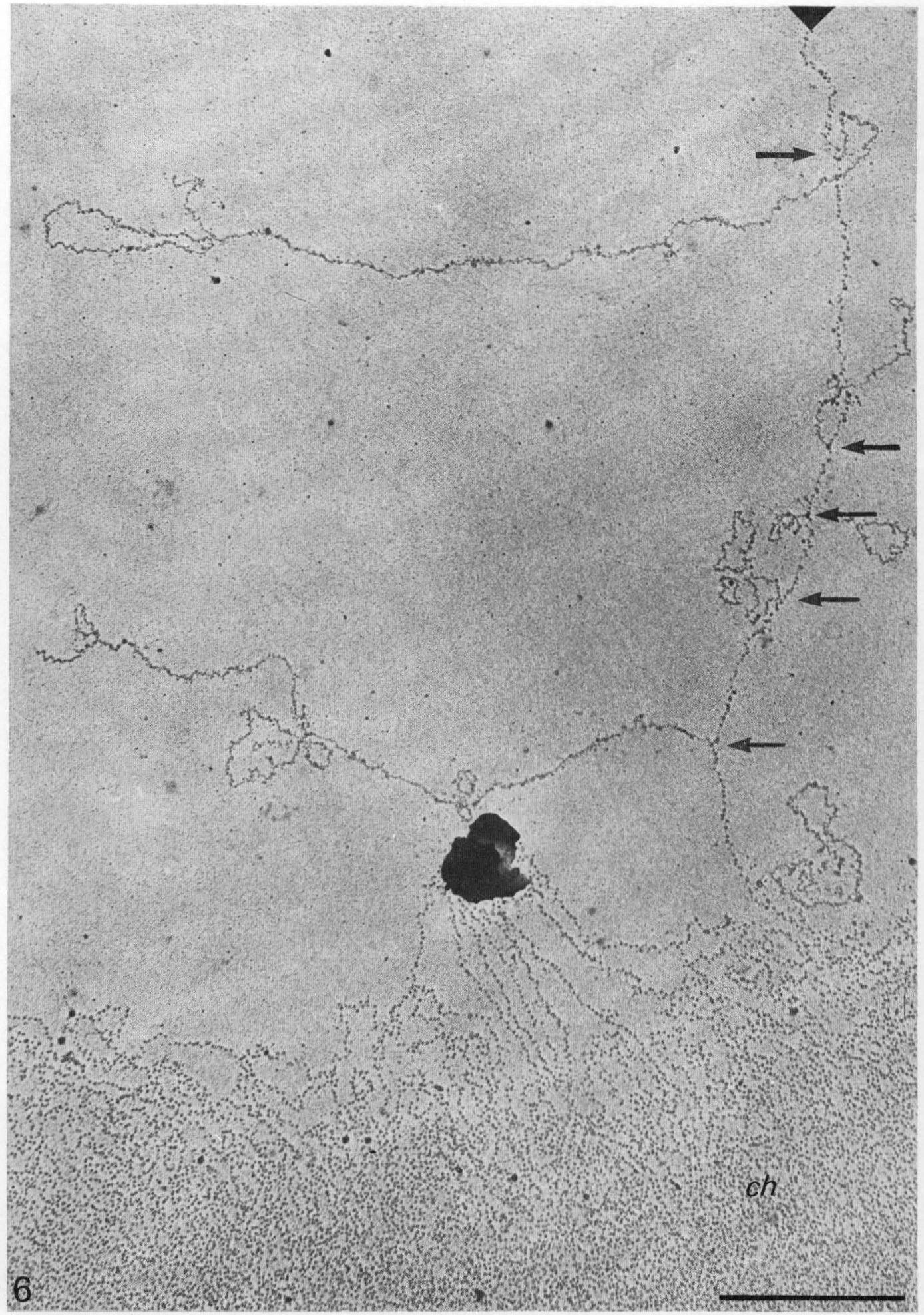


Our results based on indirect immunofluorescence demonstrate a strong crossreaction between the antibodies raised against calf thymus $\mathrm{H}_{2} \mathrm{~B}$ and the lampbrush chromosomes of the salamander Pleurodeles waltiii. While the bright fluorescence of the chromomeres is merely a confirmation of the well-established fact that transcriptionally inactive chromatin regions are associated with histones, the fluorescence along the lateral loops cannot be taken a priori as evidence for the association of $\mathrm{H}_{2} \mathrm{~B}$ with their DNA axes. A careful analysis of the fluorescence pattern shows that it reflects precisely the underlying loop morphology, i.e. the specific arrangement of the RNP matrix. A basically identical staining pattern of the lateral loops is generated after using antibodies to nuclear RNP protein, which distinguish a general protein component present in all transcripts. This similarity of the loop fluorescence also indicates that the histone antibodies react with a protein component of the RNP matrix, i.e. of the transcriptional complexes (similar results were obtained by immunoelectron microscopy; Dawson \& Sommerville, 1979). We are currently investigating the question whether the low-molecular-weight proteins present in the nuclear RNP fraction isolated from amphibian oocytes (Sommerville, I977) represent modified histones and are thus responsible for the binding of anti- $\mathrm{H}_{2} \mathrm{~B}$. Whatever the cause of the binding of anti- $\mathrm{H}_{2} \mathrm{~B}$ with the RNP matrix, the great mass of RNP fibrils, as compared to the mass of the chromatin axis to which they are attached, simply obscures in most instances an axis-specific reaction (Sommerville and Scheer, unpublished).

The possibility that loop retraction after injection of anti- $\mathrm{H}_{2} \mathrm{~B}$ is due to the interaction of the antibodies with the RNP matrix rather than with DNA-associated histones is highly unlikely considering the observation that injection of antibodies reacting specifically with transcript-associated proteins does not cause any visible morphological change of the chromosomes. Therefore, it seems justified to conclude that loop retraction is a consequence of interaction of antibodies with $\mathrm{H}_{2} \mathrm{~B}$ histone molecules associated with the transcribed DNA.

Retraction of the lateral loops of amphibian lampbrush chromosomes generally reflects inhibition of transcription. Such states occur either naturally, during very early or late phases of oogenic growth, or can be induced by drugs which interfere with the translocation of RNA polymerases along the template, like, for example, actinomycin D (Izawa, Allfrey \& Mirsky, I963; Snow \& Callan, I969). When analysed at the electron-microscopic level the initial phases of loop retraction are generally characterized by a progressive release of transcriptional complexes from the chromatin made recognizable by the occurrence of 'thinned' matrix units (Scheer, I978). The instability of transcripts as a consequence of actinomycin D inhibition

Fig. 6. Part of a chromomere (ch) with the terminal insertion site of the DNP axis of a lateral loop. This spread preparation was made $4 \mathrm{~h}$ after injection of anti- $\mathrm{H}_{2} \mathrm{~B}$. Only few and distantly spaced lateral RNP fibrils are associated with the DNP axis (their attachment sites are indicated by the arrows, the triangle in the uppermost part of the figure points to the DNP axis). The chromomeric DNP as well as the nontranscribed regions between lateral fibrils are beaded. $\times 28000$; bar indicates $\mathrm{I} \mu \mathrm{m}$. 


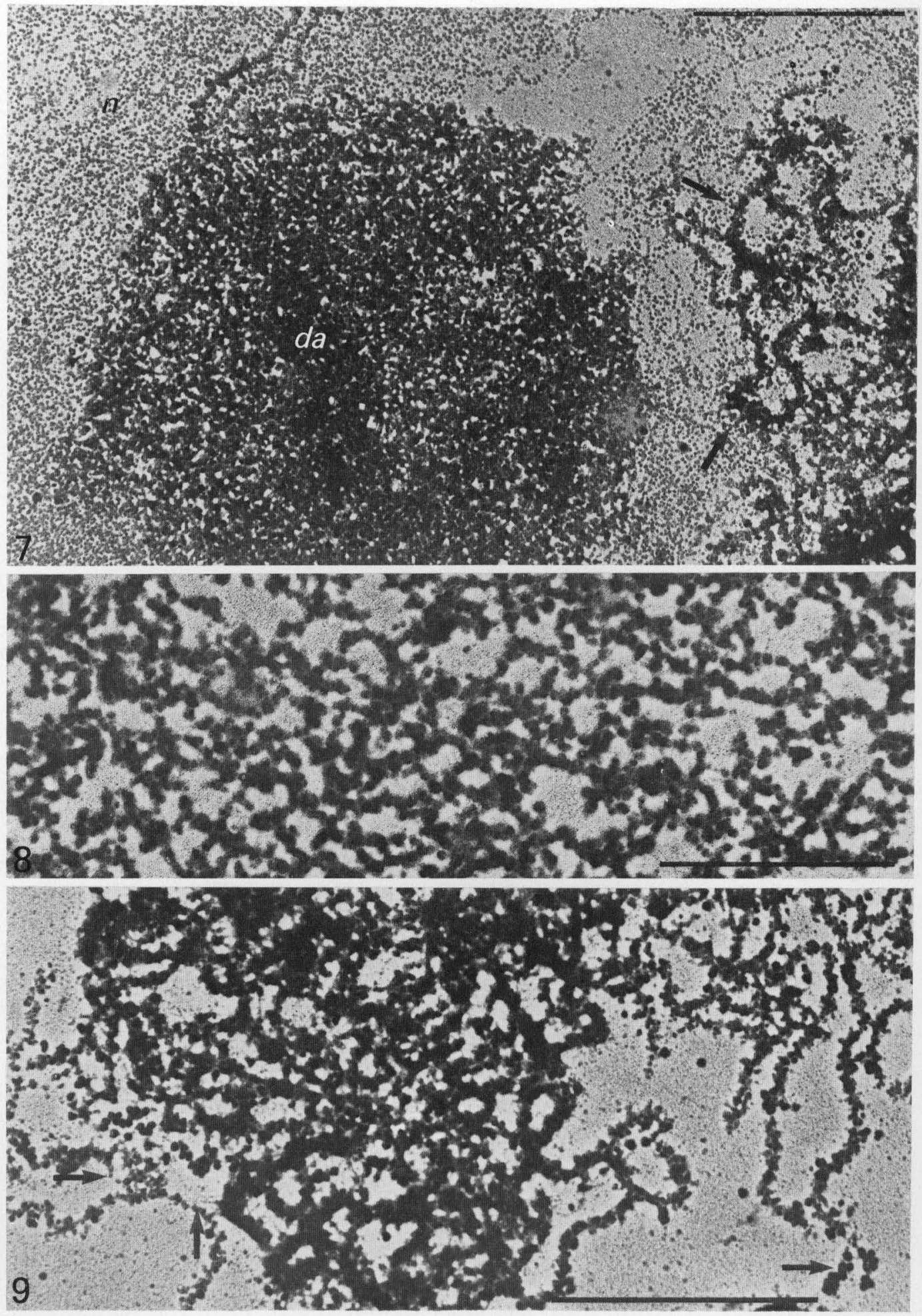


of transcription has been used for preparative purposes to increase the yield of nuclear RNP from oocytes (Sommerville, I973). Based on the electron-microscopic observation that injection of anti- $\mathrm{H}_{2} \mathrm{~B}$ induces a progressive transcript release from the loop chromatin identical to the stripping of actinomycin $\mathrm{D}$ we can furthermore conclude that binding of the antibodies to DNA-associated $\mathrm{H}_{2} \mathrm{~B}$ molecules imposes a sterical hindrance to the progression of the RNA polymerases. Thus it seems likely that histone $\mathrm{H}_{2} \mathrm{~B}$ is present in vivo in the heavily transcribed lateral loop axes.

Our demonstration of the presence of histones in transcribed, nonribosomal chromatin regions that are not compacted into nucleosomes (Franke et al. 1976; for further references see Introduction) supports the model of histones remaining permanently bound to DNA during the reversible cycle of unfolding and refolding of nucleosomes in order to allow transcription (Weintraub et al. I976; Richards et al. I978; cf. also Dieterich, Axel \& Cantor, I979; Martinson, True \& Birch, I979). It would be interesting to know whether the extended form of lampbrush loop chromatin preserves the periodic micrococcal nuclease-sensitive sites, as is the case for chromatin experimentally induced to unfold by environmental changes (Jackson \& Chalkley, 1975; Oudet, Spadafora \& Chambon, I978; Woodcock \& Frado, 1978), or whether this periodic cleavage pattern is disrupted in vivo (Wu, Wong \& Elgin, I979).

In contrast to the chromosomal transcription units, the transcription of amplified ribosomal RNA genes is not affected by injection of $\mathrm{H}_{2} \mathrm{~B}$ antibodies. It is known that inhibition of these genes by actinomycin D leads to a progressive release of transcripts from the nucleolar chromatin (Scheer, Trendelenburg \& Franke, 1975) and it is therefore reasonable to assume that if the translocation of RNA polymerases were blocked by binding of antibodies to DNA-associated histones, similar morphological effects should be observed. However, the negative outcome of the injection experiments can be explained in several ways, for instance, by assuming that the amplified nucleolar chromatin is simply inaccessible to the antibodies due to the large quantity of 'cortical' material which constitutes the bulk of the ro- $\mu \mathrm{m}$ spherical nucleoli, or that the histone antigenic determinants are altered or masked, or that histones are indeed absent from active ribosomal RNA genes. By treating electron-microscopical

Figs. 7-9. Electron micrographs of spread preparations of chromosomal material isolated $4 \mathrm{~h}$ after injection of anti- $\mathrm{H}_{2} \mathrm{~B}$ showing various structural aspects of transcriptionally inactive chromatin.

Fig. 7. Simultaneous occurrence of chromatin organized into nucleosomes $(n)$, supranucleosomal globules forming a dense aggregate $(d a)$ and $50-60-\mathrm{nm}$-thick cablelike strands (arrows). $\times 31000 ;$ bar indicates $\mathrm{I} \mu \mathrm{m}$.

Fig. 8. Higher magnification of a more dispersed region of a dense aggregate to show arrays of superbeads forming a network of $30-\mathrm{nm}$-thick chromatin fibres. $\times 69000$; bar indicates $0.5 \mu \mathrm{m}$.

Fig. 9. Thick chromatin strands with diameters ranging usually from 50 to $60 \mathrm{~nm}$ predominate in preparations dispersed only briefly under low salt conditions. They have an irregular contour and occasionally appear to disintegrate into complex arrays of superbeads (e.g. at the right arrow). The 2 arrows at left denote structural transitions into nucleofilaments. $\times 40000$; bar indicates $\mathrm{I} \mu \mathrm{m}$. 


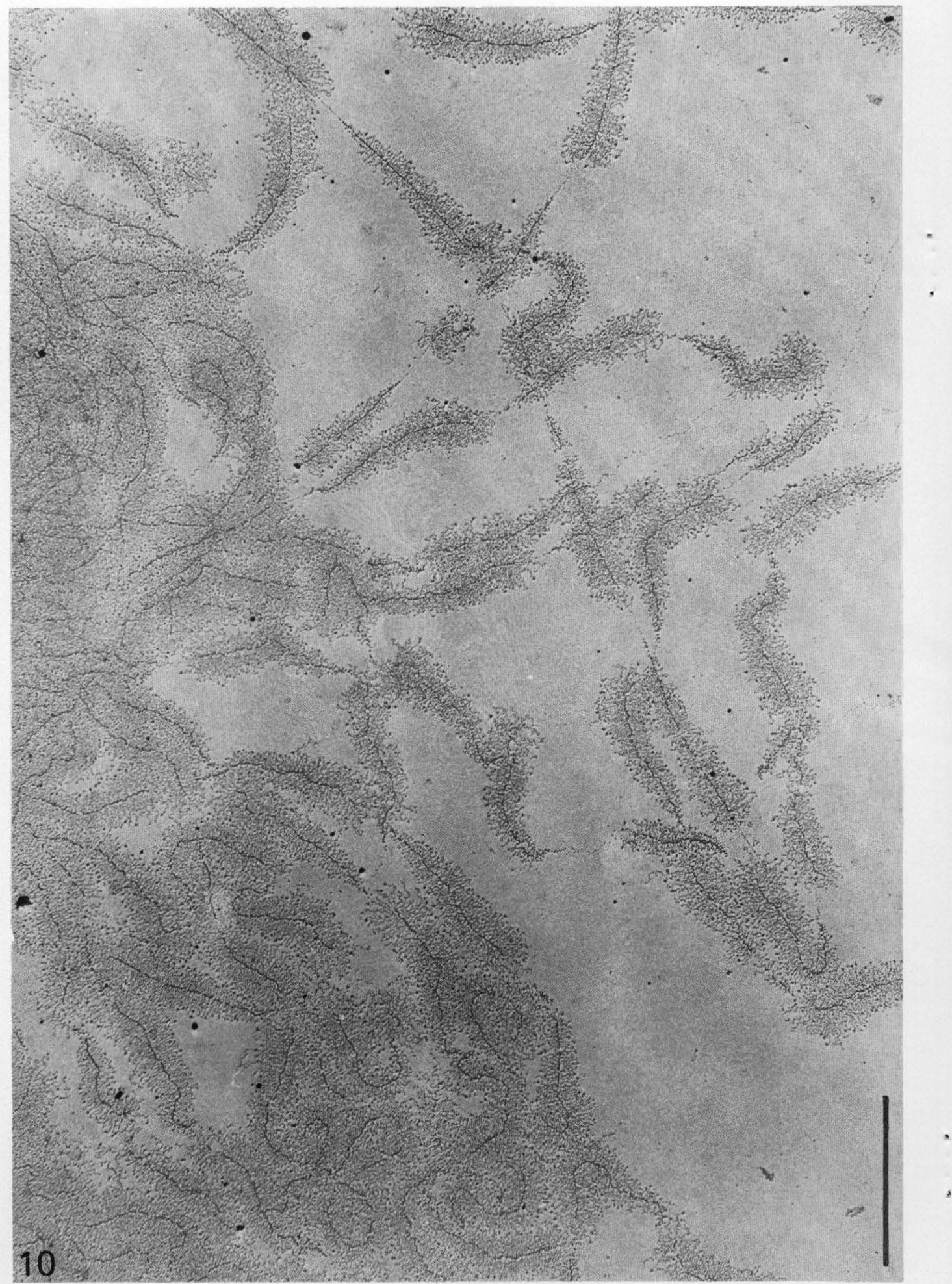

Fig. 1о. Amplified ribosomal RNA genes prepared $4 \mathrm{~h}$ after injection of anti- $\mathrm{H}_{2} \mathrm{~B}$. Most of the genes are densely covered with lateral fibrils and are morphologically indistinguishable from those of untreated oocytes. $\times 13000$; bar indicates $2 \mu \mathrm{m}$. 
spread preparations with $\mathrm{H}_{2} \mathrm{~B}$ antiserum we have recently observed a specific reaction with transcription units of Pleurodeles oocytes (Sperling, Scheer, Goldblatt \& Bustin, in preparation), a finding which makes unlikely the possibility that histones are absent or that their antigenic determinants are altered. Indeed, it is likely that histones are associated at least with the transcribed portions of the ribosomal repeating units, for this is also indicated by biochemical analyses using amplified nucleolar chromatin from Xenopus laevis oocytes (Reeder et al. 1978), but that these histones are not accessible to the antibodies in the in vivo state, either because of mechanical exclusion by the presence of nucleolar-specific skeletal elements or because the antigenic determinants are simply not exposed.

With the injection technique described here and by using ferritin-conjugated antibodies it should be possible in the near future to analyse in greater detail the distribution of histone and nonhistone components of native lampbrush chromosomes. Studies are now in progress to develop conditions which preserve the antigenantibody complex during the spreading for electron microscopy. We hope that this approach will eventually help us to localize chromosomal components at a level of resolution limited only by the size of the antibodies used and to relate their distribution to functional states of chromatin. Furthermore, injection of specific antibodies to enzymes regulating metabolic processes, like the steps of RNA cleavage and modification, should be helpful in elucidating the complex mechanism involved in the generation of final RNP products. Finally, the fact that amplified ribosomal RNA genes are unaffected by injected $\mathrm{H}_{2} \mathrm{~B}$ antibodies, contrary to chromosomal transcription, could be exploited for an analysis of the dependence of rDNA transcription, processing of pre-rRNA and nucleocytoplasmic translocation of the final products on continuing production of $5 \mathrm{~s}$ ribosomal RNA or of the specific ribosomal and preribosomal proteins.

We thank Prof. H. G. Callan for stimulating discussions and for assisting with the photography of lampbrush chromosomes. The work has been supported by the Deutsche Forschungsgemeinschaft (grant Sche $157 / 3$ ).

\section{REFERENCES}

ANGelier, N. \& LaCroix, J. C. (1975). Complexes de transcription d'origines nucléolaire et chromosomique d'ovocytes de Pleurodeles waltlii and P. poireti (Amphibiens, Urodèles). Chromosoma 5I, 323-335.

Bellard, M., Gannon, F. \& Chambon, P. (1978). Nucleosome structure. III. The structure and transcriptional activity of the chromatin containing the ovalbumin and globin genes in chick oviduct nuclei. Cold Spring Harb. Symp. quant. Biol. 42, 779-791.

BusBy, S. \& BAKKEN, A. (I979). A quantitative electron microscopic analysis of transcription in sea urchin embryos. Chromosoma 71, 249-262.

Bustin, M. (I973). Arrangement of histone in chromatin. Nature, New Biol. 245, 207-209.

Bustin, M., Goldblatt, D. \& Sperling, R. (I976a). Chromatin structure visualization by immunoelectron microscopy. Cell 7, 297-304.

Bustin, M., Kurth, P. D., Moudrianakis, E. N., Goldblatt, D., Sperling, R. \& Rizzo, W. B. (1978). Immunological probes for chromatin structure. Cold Spring Harb. Symp. quant. Biol. 42, 379-388.

Bustin, M., Simpson, R. T., Sperling, R. \& Goldblatt, D. (1977). Molecular homogeneity of the histone content of HeLa chromatin subunits. Biochemistry, N.Y. 16, 5381-5385. 
Bustin, M., Yamasaki, H., Goldblatt, D., Shani, M., Hubermann, E. \& Sachs, L. (1976b). Histone distribution in chromosomes revealed by antihistone sera. Expl Cell Res. 97, 440-444.

Callan, H. G. \& Lloyd, (I960). Lampbrush chromosomes of crested newts Triturus cristatus (Laurenti). Proc. R. Soc. B 243, I35-212.

Dawson, G. \& Sommerville, J. (I979). Localization of chromosomal proteins by immunoferritin labelling. (Submitted to Chromosoma.)

Dieterich, A. E., Axel, R. \& CANtor, C. R. (i979). Salt-induced structural changes of nucleosome core particles. F. molec. Biol. 129, 587-602.

Elgin, S. C. R. \& Weintraub, H. (I975). Chromosomal proteins and chromatin structure. A. Rev. Biochem. 44, 725-774.

Foe, V. E. (I978). Modulation of ribosomal RNA synthesis in Oncopeltus fasciatus: An electron microscopic study of the relationship between changes in chromatin structure and transcriptional activity. Cold Spring Harb. Symp. quant. Biol. 42, 723-740.

Foe, V. E., Wilkinson, L. E. \& Laird, C. D. (1976). Comparative organization of active transcription units in Oncopeltus fasciatus. Cell 9, $\mathrm{I}_{3} \mathrm{I}-\mathrm{I} 46$.

Franke, W. W., Scheer, U., Trendelenburg, M. F., Spring, H. \& Zentgraf, H. (1976). Absence of nucleosomes in transcriptionally active chromatin. Cytobiologie r3, 401434 .

Franke, W. W., Scheer, U., Trendelendurg, M. F., Zentgraf, H. \& Spring, H. (i978). Morphology of transcriptionally active chromatin. Cold Spring Harb. Symp. quant. Bicl. 42, $755-772$.

GAREL, A. \& AXEL, R. (1978). The structure of the transcriptionally active ovalbumin genes in chromatin. Cold Spring Harb. Symp. quant. Biol. 42, ;01-708.

GoldBlatt, D. \& Bustin, M. (1975). Exposure of histone antigenic determinants in chromatin. Biochemistry, N.Y. 14, I689-1695.

Gurdon, J. B. (1974). The Control of Gene Expression in Animal Development. Oxford: Clarendon Press.

Gurdon, J. B. (1976). Injected nuclei in frog oocytes: fate, enlargement and chromatin dispersal. F. Embryol. exp. Morph. 36, 523-540.

Hozier, J., Renz, M. \& Nehls, P. (1977). The chromosome fibre: evidence for an ordered superstructure of nucleosomes. Chromosoma 62, 301-3 I7.

Izawa, M., Allfrey, V. G. \& Mirsky, A. E. (I963). The relationship between RNA synthesis and loop structure in lampbrush chromosomes. Proc. natn. Acad. Sci. U.S.A 49, 544-55 I.

Jackson, V. \& Chalkley, R. (I975). The effect of urea on staphylococcal digestion on chromatin. Biochem. biophys. Res. Commun. 67, 1391-1400.

Karn, J., Vidali, G., Boffa, L. C. \& Allfrey, V. G. (1977). Characterization of the nonhistone nuclear proteins associated with rapidly labelled heterogeneous nuclear RNA. 7. biol. Chem. 252, 7307-7322.

Kierszenbaum, A. L. \& Tres, L. L. (1975). Structural and transcriptional features of the mouse spermatid genome. F. Cell Biol. 65, 258-270.

Kressmann, A., Clarkson, S. G., Telford, J. L. \& Birnstiel, M. L. (i978). Transcription of Xenopus tDNA ${ }_{1}^{\text {met }}$ and sea urchin histone DNA injected into the Xenopus oocyte nucleus. Cold Spring Harb. Symp. quant. Biol. 42, 1077-1082.

Kurth, P. D., Moudrianakis, E. N. \& Bustin, M. (1978). Histone localization in polytene chromosomes by immunofluorescence. F. Cell Biol. 78, 910-918.

Laird, D. D., Wilkinson, L. E., Foe, V. E. \& Choor, W. Y. (I976). Analysis of chromatinassociated fiber arrays. Chromosoma 56, I69-19o.

MacGregor, H. C. \& Callan, H. G. (I962). The actions of enzymes on lampbrush chromosomes. Q. Fl microsc. Sci. ro3, 173-203.

Malcolm, D. B. \& Sommerville, J. (1977). The structure of nuclear ribonucleoprotein of amphibian oocytes. F. Cell Sci. 24, I43-165.

Martinson, H. G., True, R. J. \& Birch, J. B. E. (I979). Specific histone-histone contacts are ruptured when nucleosomes unfold at low ionic strength. Biochemistry, N.Y. 18, 10821089.

McKnight, S. L., Bustin, M. \& Miller, O. L. (1978). Electron microscopic analysis of chromosome metabolism in the Drosophila melanogaster embryo. Cold Spring Harb. Symp. quant. Biol. 42, 741-754. 
McKnight, S. L. \& Miller, O. L. (I976). Ultrastructural patterns of RNA synthesis during early embryogenesis of Drosophila melanogaster. Cell 8, 305-319.

McKnight, S. L., Sullivan, N. L. \& Miller, O. L. (I976). Visualization of the silk fibroin transcription unit and nascent silk fibroin molecules on polyribosomes of Bombyx mori. Prog. Nucleic Acid Res. 19, 313-318.

Miller, O. L. \& Bakken, A. H. (I972). Morphological studies of transcription. Acta endocr., Copenh. Suppl., I68, I55-177.

Miller, O. L., Beatty, B. R. \& Hamkalo, B. A. (I972). Nuclear structure and function during amphibian oogenesis. In Oogenesis (ed. J. D. Biggers \& W. A. Schuetz), pp. I19-128. Baltimore: University Park Press.

Oudet, P., Spadafora, C. \& Chambon, P. (1978). Structure of the SV40 minichromosome and electron microscopic evidence for reversible transitions of the nucleosome structure. Cold Spring Harb. Symp. quant. Biol. 42, 301-312.

Puvion-Dutilleul, F., Bernadac, F., Puvion, E. \& Bernhard, W. (i977). Visualization of two different types of nuclear transcriptional complexes in rat liver cells. $\mathcal{F}$. Ultrastruct. Res. 58, 108-117.

Reeder, R. H., Wahn, H. L., Botchan, P., Hipskind, R. \& Sollner-Webb, B. (i978). Ribosomal genes and their proteins from Xenopus. Cold Spring Harb. Symp. quant. Biol. 42, II67-II77.

Richards, B. M., Pardon, J. F., Lilley, D. M. J., Cotter, R. I., Wooley, J. C. \& Worcester, D. L. (1978). Nucleosome sub-structure during transcription and replication. Phil. Trans. R. Soc. Lond. Ser. B 283, 287-289.

ScHEER, U. (1978). Changes of nucleosome frequency in nucleolar and non-nucleolar chromatin as a function of transcription: an electron microscopic study. Cell $\mathbf{r 3}, 535-549$.

Scheer, U., Franke, W. W., Trendelenburg, M. F. \& Spring, H. (i976). Classification of loops of lampbrush chromosomes according to the arrangement of transcriptional complexes. 7. Cell Sci. 22, 503-520.

SCHEER, U. \& Sommerville, J. (1979). Assembly of recombinant DNA into higher order chromatin structures after injection into oocyte nuclei of Pleurodeles: comparison with the structure of the endogenous lampbrush chromosomes. (Submitted to Expl Cell Res.)

Scheer, U., Spring, H. \& Trendelenburg, M. F. (I979). Organization of transcriptionally active chromatin in lampbrush chromosome loops. In The Cell Nucleus, vol. 7 (ed. H. Busch), pp. 3-47. New York: Academic Press.

Scheer, U., Trendelenburg, M. F. \& Franke, W. W. (1975). Effects of actinomycin D on the association of newly formed ribonucleoproteins with the cistrons of ribosomal RNA in Triturus oocytes. F. Cell Biol. 65, I63-179.

Scott, S. E. M. \& Sommerville, J. (1974). Location of nuclear proteins on the chromosomes of newt oocytes. Nature, Lond. 250, 680-682.

Simpson, R. T. \& Bustin, M. (1976). Histone composition of chromatin subunits studied by immunosedimentation. Biochemistry, N.Y. 19, 4305-4312.

Snow, M. H. L. \& Callan, H. G. (I969). Evidence for a polarized movement of the lateral loops of newt lampbrush chromosomes during oogenesis. F. Cell Sci. 5, I-25.

Sommerville, J. (I973). Ribonucleoprotein particles derived from the lampbrush chromosomes of newt oocytes. F. molec. Biol. 78, 487-503.

Sommerville, J. (1977). Gene activity in the lampbrush chromosomes of amphibian oocytes. In International Review of Biochemistry, Biochemistry of Cell Differentiation II, vol. I 5 (ed. J. Paul), pp. 79-156. Baltimore: University Park Press.

Sommerville, J., Crichton, C. \& Malcolm, D. B. (I978). Immunofluorescent localization of transcriptional activity on lampbrush chromosomes. Chromosoma 66, 99-1 I4.

Sommerville, J. \& Malcolm, D. B. (I976). Transcription of genetic information in amphibian oocytes. Chromosoma 55, 183-208.

Stollar, B. D. \& Ward, M. (I970). Rabbit antibodies to histone fractions as reagents for preparative and comparative studies. F. biol. Chem. 256, I261-I266.

Wasylyk, B., Thevenin, G., Oudet, P. \& Chambon, P. (I979). Transcription of in vitro assembled chromatin by Escherichia coli RNA polymerase. F. molec. Biol. 128, 4I I440. 
Weintraub, H., Worcel, A. \& Alberts, B. (1976). A model for chromatin based upon two symmetrically paired half-nucleosomes. Cell 9, 409-417.

Woodcock, C. L. F. \& Frado, L.-L. Y. (I978). Ultrastructure of chromatin subunits during unfolding, histone depletion, and reconstruction. Cold Spring Harb. Symp. quant. Biol. 42, 43-55.

WU, C., Wong, Y.-C. \& Elgin, S. C. R. (1979). The chromatin structure of specific genes: II. Disruption of chromatin structure during gene activity. Cell I6, 807-8I4.

(Received 5 Fuly 1979) 